\title{
PERAN PEMERINTAH KOTA LHOKSEUMAWE DALAM MELAKUKAN PENGAWASAN TERHADAP IZIN USAHA DAN OPERASIONAL KOPERASI SIMPAN PINJAM (studi penelitian pada koperasi simpan pinjam di Kota Lhokseumawe)
}

\author{
${ }^{1}$ Vina Melinda Limbong, ${ }^{2}$ Harun, ${ }^{2}$ Muhammad Nasir \\ ${ }^{1}$ Mahasiswa Fakultas Hukum Universitas Malikussaleh \\ 2 Dosen Fakultas Hukum Universitas Malikussaleh
}

\begin{abstract}
The objectives to be achieved in this study are to indetify andexplainthe role, obstacles and efforts of the Lhokseumawe city government in supervising the business licenses and operations of savings and load cooperatives in the city of Lhokseumawe. Supervision and inspection of savings and loan cooperatives are activities carried out cooperatives to supervise and examine cooperatives so that activities are carried out properly in accordance with statutory regulation. Based on law number 20 o 2008 concerning micro, small and medium enterprises, the main task and function of the government is to provide services that result in independence and development that creates prosperity. And according to article 19 paragraph 1 of the reulation of the minister of cooperatives and smalland medium enterprises of the Republic of Indonesia Number 11 of 2008 concerning savings and loan business licensing, it is stated that supervision of bussines licenses and/or operational permits is carried out by the minister, governors, and mayors. This study uses qualitative research, namely legal research conducted by means of field research, which is based on primary data. The results of the study indicate that there are still many illegal cooperatives found in the city of Lhokseumawe, which operate freely, as well as the lack of activeness of the department of industry, trade and cooperatives in the city of Lhokseumawe in conducting supervision and guidance, and the lack supporting facilities and infrastructure in conducting counselling. The countermeasures carried out by the Lhokseumawe city government only carried out field reviews and guidance.
\end{abstract}

Keywords : cooperatives, supervision, local government 


\section{PENDAHULUAN}

Setiap manusia harus berusaha atau bekerja untuk memenuhi tuntutannya dalam kehidupan bermasyarakat; manusia dapat melakukan kegiatan ini sendiri atau melalui badan hukum (recht person). Subyek hukum perseorangan berkumpul atau bersatu dan membentuk suatu organisasi untuk mengejar tujuan tertentu, sehingga timbullah badan hukum sebagai subyek hukum (recht person). Badan hukum disebut juga sebagai subyek hukum yang tidak wajar karena pembentukannya. ${ }^{1}$

Dalam hal ini, salah satu bentuk usaha penyedia bantuan dana adalah koperasi simpan pinjam. Banyak sekali koperasi simpan pinjam yang beroperasi di Kota Lhokseumawe ini.

Koperasi ialah organisasi ekonomi kerakyatan yang bersifat sosial, terdiri dari orangorang atau badan hukum koperasi yang membentuk suatu susunan ekonomi sebagai usaha bersama berdasarkan asas kekeluargaan, menurut Undang-Undang Nomor 12 Tahun 1967 mengenai Pokok-pokok Perkoperasian. ${ }^{2}$

Peranan koperasi Simpan Pinjam yaitu mengebangkan perekonomian masyarakat terutama bagi para anggotanya antara lain :

1. Membantu kepeluan kredit para anggota dengan syarat yang ringan.

2. Mendorong anggotanya untuk menabung secara konsisten sehingga dapat membangun modal sendiri.

3. Mendapatkan pemahaman yang lebih baik tentang koperasi.

4. Menjauhkan anggotanya dari cengkraman rentenir.

Adapun menurut Pasal 19 ayat 1 Peraturan Menteri Koperasi dan Usaha Kecil serta Menengah Republik Indonesia Nomor 11 Tahun 2018 tentang Perizinan Usaha Simpan Pinjam menyatakan ; "Pengawasan terhadap Izin Usaha dan/atau izin Operasional dilakukan oleh:

a. Menteri bagi Koperasi dengan wilayah keanggotaan lintas daerah provinsi.

b. Gubernur Koperasi dalam 1 (satu) wilayah provinsi dengan wilayah kepesertaan kabupaten/kota.

c. Bupati/walikota bagi Koperasi dengan wilayah keanggotaan dalam 1 (satu) wilayah daerah kabupaten/kota. ${ }^{3}$

Oleh karena itu, Pekmerintah Daerah mempunyai kewajiban untuk memberi izin dan mengawasi badan usaha terkhususnya usaha koperasi simpan pinjam. Peraturan Menteri Koperasi dan Usaha Kecil Menengah Republik Indonesia Nomor 17/Per/M.KUKM/IX/2015 tentang Pengawasan Perkoperasian menyatakan dalam Pasal 1 ayat (2) bahwa:

"Pengawasan dan pemeriksaan koperasi ialah kegiatan yang dilakukan oleh pejabat yang membidangi perkoperasian untuk memastikan bahwa kegiatan tersebut dilaksanakan dengan baik dan sesuai dengan peraturan perundang-undangan." ${ }^{4}$

Berdasarkan uraian diatas tujuan penelitian ini adalah untuk mengetahui bagaimana peran pemerintah Kota Lhokseumawe dalam melakukan pengawasan terhadap izin usaha dan operasional koperasi simpan pinjam serta untuk megetahui apa saja kendala dan upaya yang dilakukan oleh pemerintah Kota Lhokseumawe dalam melakukan pengawasan.

\section{METODE PENELITIAN}

\footnotetext{
${ }^{1}$ Sudikmomeertokusumo, Mengenal Hukum, (Liberty: Yogyakarta, 1986), hlm. 52.

${ }^{2}$ Pasal 3 Undang-Undang Nomor 12 Tahun 1967 Tentang Pokok-Pokok Perkoperasian.

${ }^{3}$ Peraturan Menteri Koperasi dan Usaha Kecil dan Menengah Republik Indonesia Nomor 11 Tahun 2018 tentang Perizinan Usaha Simpan Pinjam

${ }^{4}$ Peraturan Menteri Koperasi Dan Usaha Kecil Menengah Republik Indonesia Nomor 17 tahun 2015 Pengawasan Koperasi.
} 
Untuk menjawab permasalahan diatas, dalam penelitian ini ada dua persoalan yang akan dijawab, yaitu: Pertama, bagaimanakah Peran Pemerintah Kota Lhokseumawe dalam melakukan pengawasan terhadap izin usaha dan izin operasional koperasi simpan pinjam. Kedua, Apakah hambatan dan upaya penyelesaian hambatan dari pemerintah Kota Lhokseumawe dalam mengawasi izin operasional koperasi simpan pinjam?. Jenis penelitian yang digunakan dalam penelitian ini adalah kualitatif. Penelitian ini menggunakan penelitian hukum empiris/yuridis sosiologis (sociological legal research) yaitu memusatkan penelitian terhadap efektifitas hukum tersebut. ${ }^{5}$ Dengan menggunakan pendekatan yuridis sosiologis tersebut maka akan dilakukan penelitian lapangan sehingga diketahui bagaimana peran pemerintah derah dalam melakukan pengawasan terhadap izin usaha dan atau izin operasional koperasi simpan pinjam. ${ }^{6}$

\section{PEMBAHASAN}

\section{Pengertian Pemerintah Daerah}

Berdasarkan pasal 1 ayat (2) Undang-undang Nomor 32 tahun 2004 tentang Pemerintahan Daerah memberikan pengertian mengenai pemerintahan daerah yaitu penyelenggaraan urusan pemerintah oleh pemerintah daerah dan Menurut konsep otonomi dan tugas pembantuan yang diatur dalam Undang-Undang Dasar Negara Republik Indonesia Tahun 1945, DPRD diatur oleh prinsip Negara Kesatuan Republik Indonesia. Presiden Republik Indonesia yang memegang kekuasaan pemerintahan Negara Kesatuan Republik Indonesia adalah pengertian pemerintah pusat, yang selanjutnya disebut pemerintah. Selanjutnya, penyelenggara pemerintahan daerah adalah gubernur, bupati, atau walikota, dan perangkat daerah sebagai unsur birokrasi di daerah meliputi tanggung jawab kepala dinas, kepala lembaga, dan satuan kerja di lingkungan pemerintah daerah yang kesemuanya di bawah sekretariat daerah. ${ }^{7}$

Pemerintahan daerah, menurut Nimatul Huda, ialah pemerintahan yang mandiri di dalam Negara Kesatuan Republik Indonesia. ${ }^{8}$ Pemerintah daerah ialah pemerintah yang ada pada suatu daerah. Perkembangan pasca-konstitusional Indonesia, khususnya dalam pelimpahan wewenang dari pemerintah pusat kepada pemerintah daerah, terlihat dalam pelaksanaan penyelenggaraan pemerintahan. Dalam hal ini, pelimpahan atau penyerahan kewenangan yang dimaksud ialah mengenai azas desentralisasi, dimana desentralisasi itu ialah penyerahan kewenangan dari pemerintah pusat kepada pemerintah daerah otonom berdasarkan asas otonomi. ${ }^{9}$ Yang dimaksud Pemerintah Daerah dalam judul yang dibahas ialah dinas Koperindag. Dinas koperindag adalah lembaga yang memiliki tigas pokok untuk melaksanakan urusan pemerintaha daerah di bidang koperasi, UMKM, perindustrian dan perdagangan. Dalam menjalankan tanggung jawabnya untuk menumbuhkan sektor ekonomi masyarakat daerah yang difokuskan pada usaha kecil dan menengah. ${ }^{10}$

${ }^{5}$ Soejono Seokanto, Pengentar Penelitian Hukum, UI Press, Jakarta, Raja Grafindo Persada, 2003, hlm. 16

${ }^{6}$ Amiruddin, Pengantar Metode Penelitian Hukum, Jakarta, Raja Grafindo Persada, 2003, hlm.

16

${ }^{7}$ Siswanto Sunarno, Hukum Pemerintahan Daerah, Sinar Grafika, Jakarta, 2005, hlm. 5

${ }^{8}$ Ni'matul Huda, Otonomi Daerah Filosofi, Sejarah Perkembangan dan Problematika, Pustaka Pelajar, Yogjakarta, 2005, hlm. 20.

${ }^{9}$ Periksa Pasal 1 angka 8 Undang-Undang Nomor 2 Tahun 2015 Tentang Pemerintah Daerah.

${ }^{10}$ Undang-Undang No.25, Pustaka Tinta Mas, Surabaya2009, hlm 113 


\section{Pemerintahan Kota Lhokseumawe}

Kota merupakan pusat pemukiman dan kegiatan penduduk yang batas-batas administrasinya ditetapkan dalam peraturan perundang-undangan, serta permukiman yang telah menunjukkan watak dan ciri kehidupan perkotaan, menurut Pasal 1 Peraturan Menteri Dalam Negeri Nomor 2 Tahun 1987. ${ }^{11}$

Lhokseumawe adalah nama sebuah wilayah di Provinsi Aceh. Asal kata Lhokseumawe ialah "lhok dan seumawe". Lhok berarti dalam, teluk, atau palung laut, dan seumawe berarti pusaran air atau pusat dan mata air di laut sepanjang pantai Banda Sakti dan sekitarnya. ${ }^{12}$

Pemerintah Kota Lhokseumawe merupakan bagian dari sistem penyelenggaraan Pemerintahan Daerah di Indonesia. Kota Lhokseumawe disebut juga kota ialah kesatuan masyarakat hukum di provinsi yang mempunyai kewenangan khusus untuk mengatur dan mengurus sendiri urusan pemerintahan dan kepentingan masyarakat setempat sesuai dengan peraturan perundang-undangan Negara Kesatuan Republik Indonesia.

Dengan terbentuknya Pemerintah Kota Lhokseumawe berlandasan Undang-Undang Nomor 2 Tahun 2001, maka Walikota Lhokseumawe berwenang membina dan mengembangkan dunia usaha dalam rangka mendorong peningkatan perekonomian daerah melalui pertumbuhan usaha baru, khususnya di bidang industri serta perdagangan, maka perlu menciptakan peluang usaha yang seluas-luasnya. Dinas Perindustrian, Perdagangan serta Koperasi Kota Lhokseumawe yang menjadi perpanjangan tangan dari Permerintah Kota Lhokseumawe yang kemudian akan melaksanakan fungsi pengawasan terhadap pelaku usaha serta konsumen.

\section{Peran Dinas Perindustrian, Perdagangan dan Koperasi}

Dinas perindustrian, perdagangan, serta perkoperasian bertanggung jawab menyelenggarakan urusan pemerintahan di bidang perkoperasian, usaha kecil dan menengah, perindustrian, dan perdagangan berdasarkan asas otonomi, yang meliputi tugas dekonsentrasi dan tugas pembantuan, serta tanggung jawab lainnya., sesuai dengan kebijakan Gubernur dan peraturan perundang-undangan yang berlaku.

Tugas dan fungsi utama pemerintah menurut Undang-Undang Nomor 20 Tahun 2008 tentang usaha mikro, kecil, dan menengah adalah memberikan pelayanan yang mengarah pada kemandirian dan pembangunan yang mengarah pada kesejahteraan. Fungsi pemerintah dalam situasi ini adalah sebagai berikut: ${ }^{13}$

1) Pemerintah sebagai fasilitator

2) Pemerintah sebagai Regulator

3) Pemerintah sebagai motivator

\section{Perizinan}

Licence, permit (bahasa Inggris), atau vergunning ialah frasa yang digunakan untuk menggambarkan proses memperoleh lisensi (Belanda). Izin tidak lebih dari monopoli yang diberikan oleh pemerintah. Tidak ada lembaga lain yang dapat memberikan izin di luar pemerintah, yang terkait dengan pengertian kekuasaan negara atas seluruh sumber daya alam

\footnotetext{
${ }^{11}$ Totok gunawan dkk., Fakta dan Konsep Geografi, (Jakarta: Inter Plus, 2007), hlm 104.

12 www.lhokseumawekota.go.id, Sejarah Kota Lhokseumawe. Diakses melalui situs: https://www.lhokseumawekota.go.id/pem.php?id=6 pada tanggal 8 juni 2021

${ }^{13}$ Surya Abraham, Jurnal Peran Dinas Perindustrian, Perdagangan, Koperasi dan UKM ( Ilmu Permerintahan), Tahun 2016, hlm. 1047
} 
untuk kelangsungan hidup rakyat. ${ }^{14}$ Selain itu, fungsi izin ialah represif. Izin dapat digunakan untuk memecahkan masalah lingkungan yang dihasilkan oleh aktivitas manusia yang terkait dengan dasar perizinan. Artinya, perusahaan yang memperoleh izin pengelolaan lingkungan wajib menanggulangi pencemaran atau perusakan lingkungan hidup akibat kegiatan usahanya. ${ }^{15}$

Pemerintah memerlukan instrumen perizinan agar dapat menjalankan fungsinya. Hal ini dicapai melalui penerbitan keputusan administratif oleh negara. Izin diberikan untuk pendirian usaha atau kegiatan yang termasuk dalam kategori kegiatan lingkungan. ${ }^{16}$

Peraturan Menteri Dalam Negeri Nomor 20 Tahun 2008 tentang Pedoman Organisasi dan Tata Kerja Unit Pelayanan Perizinan Terpadu di Daerah, yang menyatakan bahwa izin adalah dokumen yang dikeluarkan pemerintah yang berfungsi sebagai alat bukti, menyatakan sah atau diperbolehkannya seseorang atau badan hukum untuk melakukan usaha atau kegiatan. Pemberian pengertian izin tersebut menunjukkan adanya penekanan yang kuat pada pemberian kuasa tertulis dalam bentuk dokumen, menunjukkan bahwa yang dimaksud dengan izin tidak termasuk yang diberikan secara lisan.

Pengertiaan dan Anatomi Koperasi simpan Pinjam

Koperasi ialah sekelompok orang otonom yang berkumpul secara sukarela untuk mencapai kebutuhan dan tujuan ekonomi, sosial, dan budaya mereka dengan menjalankan perusahaan koperasi yang dimiliki bersama dan diatur secara demokratis. ${ }^{17}$ Yang dimaksud dengan koperasi simpan pinjam adalah koperasi yang kegiatannya hanya berupa usaha simpan pinjam, menurut Pasal 1 ayat (2) Peraturan Pemerintah Nomor 9 Tahun 1995 yang mengatur tentang penyelenggaraan kegiatan usaha simpan pinjam oleh koperasi

Koperasi menurut Margono Djojohadi koesoemo dalam bukunya yang berjudul 10 Tahun Koperasi mengatakan bahwa koperasi adalah perkumpulan manusia seorang-seorang yang dengan sukanya sendiri hendak bekerja sama memajukan ekonominya. ${ }^{18}$

Untuk lebih memahami tentang koperasi simpan pinjam dengan komprehensif berikut adalah anatomi koperasi simpan pinjam :

1. Prinsip / sendi dasar koperasi simpan pinjam

Prinsip / sendi dasar koperasi simpan pinjam adalah norma-norma dan nilai-nilai yang menjadi acuan pokok bagi pengurus koperasi dalam menjalankan, mengelola, dan mengembangkan koperasi.

Setiap perkumpulan tertentu mempunyai tujuan yang akan dicapai dan untuk mencapai hal ini setiap perkumpulan harus membuat aturan-aturan yang akan disepakati dan dilaksanakan oleh setiap perkumpulan. Demikian pula halnya dengan koperasi, peraturan-peraturan atau tata tertib dalam koperasi dapat dilihat sebagai peraturan lalu lintas, dengan rambu-rambu tanda bahaya yang harus diperhatikan oleh seluruh pengurus dan anggota koperasi. Peraturanperaturan itulah yang dalam koperasi dihimpun berurutan yang disebut anggaran dasar.

Anggaran dasar koperasi simpan pinjam adalah seperangkat aturan dasar dan peraturan yang harus diikuti oleh semua orang yang terlibat dalam koperasi, termasuk pengurus, lembaga pemeriksa, dan anggota.

\footnotetext{
${ }^{14}$ Helmi, 2012. Hukum Perizinan Lingkungan Hidup,. Sinar Grafika : Jakarta

${ }^{15}$ Helmi,. Ibid

${ }^{16}$ Helmi,. Op,. Cit, hlm. 29

17 Agn. Suprianto, Tata Kelola Koprasi Kredit Atau Koperasi Simpan, (Yogjakarta: Cv andi
} Offset, 2015 ) hlm. 21

\footnotetext{
${ }^{18}$ Hendrojogi, Koperasi Azaz-Azaz Teori dan Praktek, (Jakarta: Rajawali Pers, 1998), cet. Ke-5,
} 
Setiap anggaran dasar koperasi simpan pinjam harus memuat pokok-pokok sebagai berikut:

a. Nama, pekerjaan, serta tempat tinggal para pendiri koperasi.

b. Nama lengkap dan Nama singkat koperasi.

c. Tempat kedudukan koperasi dan daerah kerjanya.

d. Maksud tujuan.

e. Ketegasan usaha.

f. Syarat-syarat keanggotaan.

b. Ketetapan tentang permodalan.

c. Peraturan tentang tanggung jawab anggota.

d. Peraturan tentang pimpinan koperasi, hak dan kewajiban anggota.

e. Penetapan tahun buku.

f. Ketentuan tentang sisa hasil usaha pada akhir tahun buku.

g. Ketentuan mengenai sisa kekayaan bila koperasi dibubarkan.

Dari beberapa catatan tentang koperasi simpan pinjam dapat dinyatakan bahwa yang dapat menjadi anggota koperasi simpan pinjam adalah setiap warga Indonesia yang memenuhi ketentuan-ketentuan sebagai berikut:

a. Dewasa dan mampu melaksanakan tindakan hukum.

b. Menyetujui landasan idiil, azas, dan sendi dasar koperasi.

c. Sanggup dan bersedia memenuhi kewajibannya dan melakukan haknya sebagai anggota koperasi.

Di Indonesia pada khususnya memandang koperasi sebagai bagian dari sistem ekonomi pancasila. Dan diciptakan sebagai lembaga ekonomi untuk mengurangi dan menetralisir pengaruh ekonomi kapitalis. Dengan demikian, sumber keuangan koperasi di Indonesia ada empat jenis yakni:

a. Anggota, pada hal ini keuangan anggota menjadi modal anggota. Keuangan anggota ini dimaksudkan adalah: Simpanan pokok, Yakni simpanan yang mesti dicukupi seorang saat waktu mulai menjadi anggota koperasi. Kemudian simpanan wajib, Yakni simpanan yang diharuskan terhadap anggota untuk melunasi di waktu yang ditentukan, simpanan ini bisa ditarik apabila sesuai dengan ketentuan koperasi. Dan terakhir simpanan sukarela, yakni simpanan yang besar serta memiliki waktu yang tidak ditentukan bergantung kepada kerelaan anggota atau perjanjian dengan koperasi.

b. Pinjaman. Pinjaman adalah sumber yang sering dipakai oleh koperasi, jika koperasi masih merasa kekurangan modal. Pinjaman ini dapat diambil dari anggota, dari instansi lain atau bank.

c. Hasil usaha. Sumber ini dapat diperoleh sesudah sebuah koperasi berjalan bertahun-tahun dan tidak menderita rugi, atau menderita rugi tapi dapat ditutup kembali. Hasil usaha ialah laba bersih dari semua kegiatan usaha koperasi, dan kelebihan nilai inilah yang dapat digunakan menjadi modal koperasi, setelah dikurangi biaya-biaya yang lain.

d. Penanaman modal. Sumber ini jarang diperoleh di Indonesia, sebab banyaknya saluran penanaman modal dengan pengahasilan yang lebih menarik dari pada koperasi, pemilik-pemilik modal lebih suka menanam modalnya diusaha-usaha 
lain. Lagi pula koperasi memang tidak dimaksudkan sebagai badan/ tempat penanaman modal. Karena itu sumber ini tidak berarti banyak. ${ }^{19}$

Sisa keuntungan operasional harus dikembalikan/dibagi di antara para anggota sesuai dengan jasa mereka sebagai konsekuensi dari keuntungan wajar yang diperoleh.

Dengan demikian pembagian sisa hasil usaha koperasi diatur sebagai berikut:

a. Cadangan koperasi.

b. Anggota sebanding dengan jasa yang diberi masing-masing.

c. Dana pengurus.

d. Dana pegawai dan karyawan.

e. Dana pendidikan koperasi.

f. Dana sosial.

g. Dana pembagunan.

Cara penggunaan sisa hasil usaha diatas, kecuali cadangan, cara pemanfaatan sisa hasil usaha diatur pada anggaran dasar dengan mengutamakan kepentingan koperasi. Untuk melindungi modal koperasi, cadangan tidak boleh dialihkan kepada anggota, bahkan pada saat pembubarannya. Sedangkan pemakaian dana sosial diatur oleh rapat anggota serta bisa dibagikan antara lain kepada fakir miskin, yatim piatu, panti-panti sosial, dan lain-lain. ${ }^{20}$

\section{Tujuan dan Fungsi Koperasi Simpan Pinjam}

koperasi bertujuan untuk memajukan kesejahteraan anggota pada khususnya serta masyarakat pada umumnya, serta turut serta membangun tatanan perekonomian nasional, menurut Pasal 3 Undang-Undang Nomor 25 Tahun 1992 mengenai Perkoperasian. Koperasi Simpan Pinjam semestinya mengadopsi peraturan yang mengatur tanggung jawab pengurus, pengawas, pengurus, dan yang terpenting rapat anggota untuk mencapai tujuannya. Dewan berfungsi sebagai pusat pengambilan keputusan, penasihat, dan penjaga jangka panjang organisasi, serta orang yang bisa dipercaya.

Seperti yang terpapar pada Peraturan Menteri Nomor 15 Tahun 2015 usaha simpan pinjam yang dilaksanakan oleh koperasi yang beroperasi dalam bidang lembaga keuangan memiliki visi, misi serta tujuan yang mengarah agar aspirasi serta keperluan ekonomi anggota koperasi dapat tercapai sehingga perkonomian anggota koperasi dapat berkembang menjadi kuat, sehat mandiri serta tangguh.

Salah satu tujuan KSP Kopdit adalah agar para anggotanya dapat memperoleh pinjaman dengan cepat dan dengan suku bunga yang murah.

Tujuan dibentuknya koperasi simpan pinjam ialah untuk memberikan manfaat baik bagi anggota maupun masyarakat. Berdirinya sebuah koperasi diharapakan dapat memberikan kontribusi untuk pertumbuhan ekonomi nasional.

Selanjutnya peran Indonesia dituangkan dalam Pasal 4 Undang-Undang Nomor 25 Tahun 1992 tentang Perkoperasian, yang menyatakan:

1. Membangun dan mengembangkan potensi dan kemampuan ekonomi anggota pada khususnya serta warga pada umumnya untuk meningatkan kesejahteran ekonomi serta sosial.

2. Berperan serta secara aktif dalam upaya mempertinggi kualitas kehidupan manusia dan masyarakatnya.

\footnotetext{
${ }^{19}$ Ibid, hlm 8-9

${ }^{20}$ Ibid, hlm. 10-11
} 
3. Penguatan ekonomi kerakyatan sebagai tumpuan kekuatan dan ketahanan ekonomi nasional, dengan koperasi sebagai pilar guru.

4. Berusaha mewujudkan dan membangun perekonomian nasional yang berlandaskan asas kekeluargaan dan demokrasi ekonomi serta merupakan upaya bersama. ${ }^{21}$

\section{HASIL PENELITIAN}

\section{Pelaksanaan Pemerintah Terhadap Pemberian Izin Usaha dan Operasional Koperasi Simpan Pinjam di Kota Lhokseumawe}

Dinas Penanaman Modal Pelayanan Terpadu Satu Pintu dan Tenaga Kerja Kota Lhokseumawe merupakan perpanjangan tangan dari Pemerintah Kota Lhokseumawe yang akan menerbitkan izin pendirian tempat usaha setelah sebelum nya pemohon melengkapi segala syarat yang telah ditetapkan seperti Izin Usaha Perdagangan (SIUP) untuk perizinan pendirian minimarket, supermarket. Mekanisme pelaksanaan pelayanan perizinan ini diatur lebih lanjut melalui Peraturan Walikota yang tertera didalam Keputusan Walikota Lhokseumawe Nomor : 56 Tahun 2002 Tentang Pemberian Surat Izin Usaha Perdagangan, Izin Usaha Industri, Tanda Daftar Industri dan Tanda Daftar Perusahaan.

Pendaftaran izin mendirikan koperasi di Dinas Penanaman Modal Pelayanan Terpadu Satu Pintu dan Tenaga Kerja (DPMPTSP) Kota Lhokseumawe sekarang dilakukan secara Online melalui oss.co.id. kendala dari system Online yang sekarang ini berlaku ialah masalah di NIK ketika pemohon belum melakukan regisrasi di capil itu akan bermasalah setelah masalah NIK selesai kemudian akan bermasalah di pajak nya ketika si pemohon belum melaporkan maka pemohon tidak dapat melakukan izin dan apabila semua nya selesai maka izin dapat dikeluarkan.

Kemudian permasalahan dilapangan yang penulis temukan ialah banyak nya koperasikoperasi bodong atau yang dikenal dengan sebutan lintah darat yang aktif di Kota Lhokseumawe dengan surat resmi mendirikan usaha dari DPMPTSP dan kemudian itu menjadi salah satu kelemahan dari sytem dinas sekarang ini, Kebijakan dari Pemerintah melewatkan birokrasi Pemerintah Daerah akhirnya seperti ini kasus yang banyak terjadi di Kota Lhokseumawe.

Dinas Perindustrian Perdagangan dan Koperasi merupakan instansi yang melakukan koordinasi bersama Badan Pelayanan Perizinan Terpadu Satu Pintu dan Tenga Kerja Kota Lhokseumawe dalam hal menerbitkan izin pendirian tempat usaha. Pemerintah berkewajiban untuk memberikan bimbingan, pengawasan, perlindungan dan fasilitas terhadap Koperasi. Pemerintah tidak dapat bersikap pasif melainkan besikap aktif, karena sikap pasif dalam hal keadaan koperasi mempunyai banyak kelemahan dan dengan sendirinya pemerintah membiarkan lambatnya pertumbuhan dan perkembangan koperasi, padahal telah kita ketahui demikian pentingnya koperasi dalam membantu meningkatkan perekonomian masyarakat yang (relatif) lemah dan demikian besarnya sumbangan koperasi terhadap keberhasilan pembangunan yang sedang kita galakkan ${ }^{22}$.

Kebijakan pemerintah pada hakekat nya memberikan kebebasan yang wajar bagi koperasi untuk mengatur kehidupan sendiri dalam rangka mewujudkan landasaan idiil, pelaksanaan azas serta sendi dasarnya, dengan kebebasan itu hendaknya dari pihak koperasi sendiri menyadari bahwa setiap gerak langkahnya adalah emban amanat masyarakat/ para

\footnotetext{
${ }^{21}$ Hendrojogi, op.cit, hlm. 345-346

${ }^{22}$ G. Kartasapoetra, Koperasi Indonesia, Pt. Rineka Cipta, Jakarta, 2007, hlm. 175
} 
anggota koperasi simpan pinjam itu sendiri, sehingga tidak boleh menyimpang dari pancasila dan UUD 1945, koperasi adalah alat penegak demokrasi ekonomi yang bertujuan untuk meningkatkan kesejahteraan hidup para anggotanya khususnya dan masyarakat pada umumnya. Dalam hal ini pemerintah diperlukan waktu setiap saat untuk turun tangan guna memberikan pengamanan terhadap azas dan sendi dasar koperasi serta kebijaksanaan pemerintah, baik guna kepentingan gerakan koperasi itu sendiri maupun untuk keperluan masyarakat.

Ada beberapa ketentuan jumlah modal pendirian koperasi untuk jenis koperasi simpan pinjam, hal tersebut diatur dalam Pasal 17 Peraturan Menteri Koperasi dan Usaha Kecil dan Menengah No.15/PER/M.KUKM/IX?2015 Tahun 2015 Tentang Usaha Simpan Pinjam oleh Koperasi yang telah diubah dengan Peraturan Menteri Koperasi dan Usaha Kecil dan Menengah No.02/PER/M.KUKM/II/2017 Tahun 2017 Tentang perubahan Perturan Menteri Koperasi dan UKM No.15/PER/M.KUKM/IX?2015 Tahun 2015 Tentang Usaha Simpan Pinjam Oleh Koperasi.

Di dalam perubahan tersebut tidak merubah pasal 17 Peratura Menteri Koperasi dan Usaha Kecil dan Menengah No.15/PER/M.KUKM/IX?2015 Tahun 2015 yang ketentuan modal usaha awal KSP Primer dan KSP Sekunder sebagai berikut :

1. Modal usaha pada setiap pendirian KSP Primer dan KSP Sekunder yang dihimpun dari simpoanan pokok dan simpanan wajib anggtanya dan dapat ditambah dengan hibah.

2. Modal usaha awal KSP Primer sebagaimana dimaksud pada ayat (1) dalam bentuk deposito pada bank pemerintah dengan rincian sebagai berikut :

a) Modal KSP Primer dengan wilayah keanggotaan dalam daerah Kabupaten/Kota ditetapkan sebesar Rp.15.000.000,- (lima belas juta rupiah).

b) Modal KSP Primer dengan wilayah keanggotaan lintas daerah Kabupaten/Kota dalam 1 (satu) daerah Provinsi ditetapkan sebesar Rp.75.000.000,00 (tujuh puluh lima juta rupiah).

c) Modal KSP Primer dengan wilayah kenggotan lintas daerah provinsi ditetapkan sebesar Rp.375.000.000,00 (tiga ratus tujuh puluh lima juta rupiah).

3. Modal usaha awal KSP Sekunder sebagiamana dimaksud pada ayat (1) dalam bentuk deposito pada Bank Pemerintah dengan rincian sebagai berikut :

a) Modal KSP Sekunder dengan wilayah keanggotaan dalam daerah Kabupaten/Kota ditetapkan sebesar Rp.50.000.000,00 (lima puluh juta rupiah).

b) Modal KSP Sekunder dengan wilayah keanggotaan lintas daerah Kabupaten/Kota dalam 1 (satu) daerah Provinsi ditetapkan sebesar Rp.150.000.000,00 (seratus lima puluh juta rupiah).

c) Modal KSP Sekunder dengan wilayah keanggotaan lintas daerah Provinsi ditetapkan sebesar Rp.500.000.000,00 (lima ratus juta rupiah).

Menurut data dari Dinas Perindustrian, Perdagangan dan Koperasi Kota Lhokseumawe terdapat sebanyak 204 unit usaha koperasi yang terdiri dari : 
Tabel Jumlah Koperasi di Kota Lhokseumawe Tahun 2020

\begin{tabular}{|l|l|}
\hline 26 Unit & Koperasi Pegawai Negeri (KPN) \\
\hline 14 Unit & KOPKAR \\
\hline 7 Unit & PRIMKOPAD \\
\hline 3 Unit & Koperasi Unit Desa (KUD) \\
\hline 9 Unit & Koperasi Serba Usaha (KSU) \\
\hline 7 Unit & Koperasi Produsen \\
\hline 6 Unit & Koperasi Konsumsi, \\
\hline 1 Unit & Koperasi Mahasiswa \\
\hline 18 Unit & Koperasi Niaga \\
\hline 6 Unit & Koperasi Pedagang Pasar (KOPPAS) \\
\hline 6 Unit & Koperasi Pedagang Kecil \\
\hline 19 Unit & Koperasi Wanita (KOPWAN) \\
\hline 19 Unit & Koperasi Industri \& Kerajinan (KOPINKRA) \\
\hline 2 Unit & Koperasi Pemuda \\
\hline 1 Unit & KOPTI \\
\hline 8 Unit & KOPPONTREN \\
\hline 3 Unit & Koperasi Angkutan \\
\hline 23 Unit & Koperasi Nelayan dan Perikanan \\
\hline 5 Unit & Koperasi Peternakan \\
\hline 10 Unit & Koperasi Pertanian \\
\hline 1 Unit & Koperasi Simpan Pinjam \\
\hline 3 Unit & Koperasi Perbengkelan \\
\hline 1 Unit & Koperasi Konsultan \\
\hline 1 Unit & Koperasi Jasa \\
\hline 1 Unit & Koperasi Buruh \\
\hline
\end{tabular}

Sumber: Dinas Perindustrian, Perdagangan dan Koperasi Kota Lhokseumawe, 2020

\section{Peran Dinas Perindustrian Perdagangan dan Koperasi Kota Lhokseumawe dalam Melakukan Pengawasan Terhadap Koperasi Simpan Pinjam di Kota Lhokseumawe}

Pembinaan merupakan suatu proses atau pengembangan yang mencakup urutan-urutan pengertian, diawali dengan mendirikan, membutuhkan, memelihara pertumbuhan tersebut yang disertai usaha-usaha perbaikan, menyempurnakan, dan mengembangkannya. Pembinaan tersebut menyangkut kegiatan perencanaan, pengorganisasian, pembiayaan, koordinasi, pelaksanaan, dan pengawasan suatu pekerjaan untuk mencapai tujuan hasil yang maksimal.

Hasil dari temuan penulis dilapangan menunjukkan bahwa masih banyaknya koperasi yang tidak lagi beroperasi yang menjadi beban bagi pemerintah Kota Lhokseumawe khususnya Dinas Perindustrian, perdagangan dan Koperasi Kota Lhokseumawe dalam membina dan mengawasi dan mengembangkan koperasi yang ada di Kota Lhokseumawe.

Berdasarkan data dari 4 Tahun lalu, pada Tahun 2018 jumlah koperasi di Kota Lhokseumawe sebanyak 300 unit Koperasi. Dan pada Tahun 2019-2021 data koperasi yang masih aktif, tidak aktif belum dapat diberikan. 
Tabel Daftar Keterangan Koperasi Berdasarkan Kecamatan Kota Lhokseumawe

\begin{tabular}{|l|l|l|l|l|l|l|l|l|l|l|l|}
\hline \multirow{2}{*}{ No } & \multirow{2}{*}{$\begin{array}{l}\text { Kecama } \\
\text { tan }\end{array}$} & \multicolumn{2}{|l|}{ Tahun } & $\mathbf{2 0 1 6}$ & \multicolumn{10}{|l|}{$\mathbf{2 0 1 7}$} & \multicolumn{2}{l|}{$\mathbf{2 0 1 8}$} \\
\cline { 2 - 12 } & $\mathbf{A}$ & TA & T & $\mathbf{A}$ & TA & T & A & TA & BB & T \\
\hline $\mathbf{1}$ & $\begin{array}{l}\text { Muara } \\
\text { satu }\end{array}$ & 28 & 15 & $\mathbf{4 3}$ & 16 & 29 & $\mathbf{4 5}$ & 18 & 18 & 9 & $\mathbf{4 5}$ \\
\hline $\mathbf{2}$ & $\begin{array}{l}\text { Muara } \\
\text { Dua }\end{array}$ & 36 & 24 & $\mathbf{6 0}$ & 20 & 40 & $\mathbf{6 0}$ & 21 & 30 & 10 & $\mathbf{6 1}$ \\
\hline $\mathbf{3}$ & $\begin{array}{l}\text { Blang } \\
\text { Mangat }\end{array}$ & 102 & 54 & $\mathbf{1 5 6}$ & 64 & 93 & $\mathbf{1 5 7}$ & 69 & 71 & 22 & $\begin{array}{l}\mathbf{1 6} \\
\mathbf{5}\end{array}$ \\
\hline $\mathbf{4}$ & $\begin{array}{l}\text { Banda } \\
\text { Sakti }\end{array}$ & 25 & 7 & $\mathbf{3 2}$ & 19 & 13 & $\mathbf{3 2}$ & 19 & 6 & 7 & $\mathbf{3 2}$ \\
\hline Jumlah & $\mathbf{1 9 1}$ & $\mathbf{1 0 0}$ & $\mathbf{2 9 1}$ & $\mathbf{1 1 9}$ & $\mathbf{1 7 5}$ & $\mathbf{2 9 4}$ & $\mathbf{1 2 7}$ & $\mathbf{1 2 5}$ & $\mathbf{4 8}$ & $\begin{array}{l}\mathbf{3 0} \\
\mathbf{0}\end{array}$ \\
\hline
\end{tabular}

Sumber:Dinas Perindustrian, Perdagangan dan Koperasi Kota Lhokseumawe, 2018

Keterangan:

A: Aktif

TA:Tidak Aktif

BB:Bubar

T:Total

Adapun sebab terjadinya ketidak aktifan nya koperasi dan koperasi mengalami pembubaran yang ada di Kota Lhokseumawe yaitu tidak melakukan rapat anggota tahunan selama 2 tahun berturut-turut dan tidak distrornya simpanan wajib dan simpanan pokok kepada koperasi dimana 2 (dua) setoran ini menjadi modal koperasi dalam menjalankan usahanya, dalam hal ini yang termasuk dalam Undang-Undang No.25 Tahun 1992 Bab VII Pasal 41 Ayat (1) Menjelaskan bahwa Modal Koperasi dapat berasal dari Modal Sendiri dan Modal Pinjaman, Kemudian diatur pada ayat (2) yang Menyatakan Bahwa Modal Sendiri Berasal dari Simpanan Pokok, Simpanan Wajib, Dana Cadangan dan Hibah. Kemudian Dalam Bab VI Pasal 26 Ayat (1) Menjelaskan Tentang Rapat Anggota yang dilakukan Paling Sedikit Sekali Dalam Satu Tahun dan Ayat (2) Menyebutkan Rapat untuk Mengesahkan Pertanggung Jawaban Pengurus diselenggarakan Paling lambat 6 (enam) Bulan setelah Tahun Buku Lampau ${ }^{23}$.

Peraturan Mentri Koperasi dan Usaha Kecil dan Menengah Republik Indonesia Nomor 10/per/M.KUKM/IX/2015 Tentang Kelembagaan Koperasi pada X Pasal 58 Ayat (3) menegaskan bahwa Bupati/Walikota melakukan pembinaan dan pengawasan dan kelembagaan usaha koperasi yang wilayah keanggotaannya berada dalam 1 (satu) Kabupaten/Kota, sedangkan Ayat (4) menyatakan bahwa pembinaan dan pengawasan kelembagaan dan usaha dilakukan oleh Satuan Kerja Perangkat Daerah yang membidangi koperasi.

23 Jurnal Ilmu Administrasi Bisnis, "Strategi Pemerintah Kota Lhokseumawe dalam Pembinaan Koperasi (studi Dinas Perindustrian Perdagangan dan Koperasi Kota Lhokseumawe)" Vol. 3 No. 2 ,2020. hlm. 131 
Akan tetapi, yang terjadi dilapangan tidak semua koperasi yang ada di Kota Lhokseumawe mendapat pembinaan, padahal Pemerintah Kota Lhokseumawe telah merencanakan berbagai program salah satunya program Peningkatan Kelembagaan Koperasi yang bertujuan meningkatkan kesejahteraan anggota koperasi dan meningkatkan kelembagaan dan manajemen koperasi melalui berbagai kegiatan seperti Penilaian Kesehatan Koperasi Simpan Pinjam atau Usaha Koperasi, Pembinaan dan Pembubaran Koperasi, Pelatihan Manjemen Koperasi dan Penelitian Akuntansi, akan tetapi yang menjadi penghambatnya ialah keterbatasan anggaran sehingga tidak semua koperasi yang ada di Kota Lhokseumawe diikutsertakan dalam program tersebut.

Koperasi simpan pinjam Baitul Qiradh Afdhal yang berdiri di Jl. Merdeka No.15-16 Kota Lhokseumawe yang bergerak pada simpan pinjam adalah salah satu koperasi yang masih berjalan aktif hingga saat ini berdiri sejak tahun 2007 dengan kurang lebih 3000 jumlah nasabah, mempunyai kantor cabang di Kecamatan Lhoksukon. tiga tahun belakangan ini koperasi simpan pinjam ini tidak sama sekali mendapatkan perhatian dari pemerintah khusus nya dari disperindag kop, bahkan untuk bertemu dan berbincang dengan bagian koperasi di disperidag kop pun sulit. Padahal koperasi simpan pinjam baitul qiradh afdhal sangat ingin mendapat dukungan, arahan untuk menambah program-program yang dapat membantu perekonomian masyarakat Kota Lhokseumawe.

Hasil temuan penulis dilapangan menjukkan bahwa, Dinas Perindustrian, Perdagangan dan Koperasi Kota Lhokseumawe berpendapat bahwa, koperasi merupakan yang berbadan hukum akan tetapi mereka tidak boleh ada dari pihak luar yang mengintervensi akan koperasi tersebut. Sehingga pembinaan yang diberikan oleh Dinas Perindustrian, Perdagangan dan Koperasi Kota Lhokseumawe dilakuka apabila koperasi meminta bantuan untuk dibina sesuai dengan kendala yang dihadapinya sehingga dinas tidak hanya membina dalam waktu hari aktif akan tetapi membina saat ada kesempatan seperti adanya Rapat Anggota Tahunan serta mengindentifikasi koperasi yang tidak aktif lagi sehingga dapat membubarkan koperasi tersebut.

Koperasi Baitul Qiradh Afdhal adalah koperasi simpan pinjam yang berbasis syariah yang mendapat dukungan positif dari masyarakat Kota Lhokseumawe, akan tetapi Pemerintah Kota Lhokseumawe sama sekali tidak memberikan apresiasi nya kepada Koperasi Baitul Qiradh Afdhal. Bagaimana bisa koperasi maju sedangkan dukungan dari pemerintah nya sangat kurang.

Pembinaan dan pengawasan terhadap sebuah organisasi atau lembaga merupakan hal yang penting karena menyangkut beberapa aspek penting untuk melaksanakan kepastian dalam tujuan sebuah lembaga tersebut. Pembinaan merupakan sarana yang harus sering dilaksanakan secara baik kepada sebuah lembaga pembinaan tersebut menyangkut kebutuhan kinerja potensi yang dimiliki oleh para pengurus lembaga. Pembinaan bisa diberikan melalui pendidikan dalam hal koperasi seperti memberikan pembelajaran terhadap koperasi dan memberikan penyuluhan mengenai mekanisme tata kelola pengkroprasian.

Di Kota Lhokseumawe pembinaan koperasi dilakukan oleh bidang pengawasan koperasi dari DISPERINDAG KOP Kota Lhokseumawe, pembinaan ada di lakukan apabila terjadi masalah pada koperasi, misal nya ada koperasi yang sudah lama beroperasi akan tetapi tidak lagi ada anggota-anggota nya. Koperasi itu akan dibina, diarahkan sebelum akhir nyadi tutup. Penututupan koperasi juga tidak dapat dilakukan begitu saja oleh bagian pengawasan, penutupan koperasi harus melalui proses terlebih daluhu. Tinjauan lapangan, laporan dari masyarakat, laporan tahunan dari koperasi tersebut dan harus di dengan kawalan dari pihak berwajib.

Pengawasan merupakan aspek penting yang berkaitan dengan implementasi kepastian dari tujuan lembaga, pengawasan merupakan perpanjangan terhadap pembinaan yang 
dilaksanakan untuk mengevaluasi apakah pengerjaan dalam pembinaan tersebut sudah sesuai dengan apa yang telah diberikan oleh pembinaan tersebut, sehingga perkembangan koperai sebagai betuk usaha yang diabdikannya untuk masalah jasa bisa sejalan dengan amanat peraturan yang ada.

Pengawasan koperasi yang telah dilakukan oleh disperindag kop Kota Lhokseumawe pada koperasi-koperasi yang ada di Kota Lhokseumawe. Pengawasan dilakukan dengan turun ke lapangan, melakukan kunjungan langsung ke koperasi untuk mengetahui bagaimana perkembangan dan mendata koperasi-koperasi yang masih terdaftar aktif akan tetapi tidak beroperasional dengan semestinya.

Salah satu alasan DISPERINDAG KOP dalam melakukan pengawasan adalah adanya koperasi-koperasi ilegal yang dengan lancar nya beroperasional di Kota Lhokseumawe, koperasi-koperasi tersebut beroperasi di daerah-daerah perkampungan dengan sasaran ibu-ibu rumah tangga dan penjual-penjual di pajak.

Kendala yang dihadapi oleh Disperindag kop yang melakukan tinjauan lapangan adalah tidak ditemukannya aktivitas di rumah yang di duga digunakan sebagai kantor koperasi-koperasi "bodong" tersebut, ibu anisawati sebagai tim pengawas dari disperindag kop menambahkan bahwa pengecekan dilokasi sudah dilakukan akan tetapi tidak ada orang di rumah tersebut dan saat mendatangi kediaman geuchik gampong sekitar juga beliau tidak mengetahui bahwa rumah tersebut digunakan sebagai kantor koperasi yang beliau tau ada orang yang menyewa rumah tersebut.

Masalah yang peneliti temui dalam melakukan penelitian yaitu banyaknya peneliti temukan koperasi-koperasi "Bodong" yang beroperasional dengan bebas di Kota Lhokseumawe. Koperasi dengan surat izin resmi dari Dinas Penanaman Modal Pelayanan Terpadu Satu Pintu dan Tenaga Kerja itu tidak resmi karena tidak mendaftarkan usahanya itu ke disperindag Kop Kota Lhokseumawe.

Dinas Perindustrian Perdagangan dan Koperasi tidak pernah mendapatkan laporan dari koperasi-koperasi "bodong" tersebut. Dalam kasus koperasi-koperasi "bodong" ini Bagian pengawasan dari Dinas Peridustrian Perdagangan dan Koperasi melakukan tinjauan kelapangan mendatangi rumah-rumah yang diduga sebagai kantor dari koperasi "bodong" tersebut.

Upaya yang dilakukan oleh Dinas Perindustrian, Perdagangan dan Koperasi Kota Lhokseumawe dalam hal penanganan koperasi-koperasi "bodong" adalah melakukan pembinaan kepada koperas lalu akan melaporkan koperasi tersebut ke geuchik gampong setempat sebelum dilaporkan ke aparat berwajib untuk ditangani lebih lanjut.

Di lihat dari segi ekonomi kehadirah koperasi-koperasi "bodong" ini sangat lah membantu keuangan masyarakat menengah kebawah, koperasi-koperasi "bodong" ini sangat memanfaat kan waktu yang tepat untuk masuk ketengah-tengah masyarakat yang sedang terdesak biaya dengan tawaran yang sangan mudah untuk mendapatkan uang dan dalam jangka waktu yang singkat juga.

\section{KESIMPULAN}

Berdasarkan hasil penelitian dan pembahasan diatas, maka kesimpulan yang dapat diambil adalah:

1. Banyak nya ditemukan koperasi-koperasi atau yang sering disebut sebagai lintah darat/koperasi bodong yang beroperasi dengan izin pendirian usaha yang legal dari dinas penanaman modal pelayanan terpadu satu pintu dan tenaga kerja akan tetapi 
koperasi yang beroperasi tidak terdaftar di dinas perindustrian, perdagangan dan koperasi kota lhokseumawe.

2. Upaya penanggulangan yang dilakukan oleh pemerintah kota lhokseumawe yaitu hanya melakukan sebatas tinjauan lapangan dan memberikan pembinaan.

3. Kendala yag ditemukan oleh pemerintah kota lhokseumawe dalam melakukan penawasan terhadap koperasi simpan pinjam yaitu dinas peridutrian, perdagangan dan koperasi kota lhokseumawe kurang aktif dalam melaksanakan pembinaan, kurang memberikan sarana dan prasarana pendukung dalam melaksanakan pembinaan dan penyuluhan terhadap koperasi simpan pinjam.

\section{DAFTAR PUSTAKA}

Amiruddin; 2003. Pengantar Metode Penelitian Hukum, Raja Grafindo Persada, Jakarta

Agn. Suprianto; 2015, Tata Kelola Koprasi Kredit Atau Koperasi Simpan, Cv andi Offset, Yogjakarta

Fakultas Hukum Universitas Malikussaleh 2016; 2016, Buku Panduan Penulisa,Tugas Akhir Skripsi,

G. Kartasapoetra; 2007, Koperasi Indonesia, Pt. Rineka Cipta, Jakarta

Hendrojogi; 1998, Koperasi Azaz-Azaz Teori dan Praktek, Badan Diktat Debdagri, Jakarta

Helmi; 2012. Hukum Perizinan Lingkungan Hidup,. Sinar Grafika : Jakarta

Jurnal Ilmu Administrasi Bisnis; 2020, "Strategi Pemerintah Kota Lhokseumawe dalam Pembinaan Koperasi (studi Dinas Perindustrian Perdagangan dan Koperasi Kota Lhokseumawe)" Vol. 3 No. 2

Ni'matul Huda; 2005, Otonomi Daerah Filosofi, Sejarah Perkembangan dan Problematika, Pustaka Pelajar, Yogjakarta

Soejono Seokanto; 2003, Pengentar Penelitian Hukum, UI Press, Raja Grafindo Persada, Jakarta

Siswanto Sunarno; 2005, Hukum Pemerintahan Daerah, Sinar Grafika, Jakarta

Surya Abraham; 2016, Jurnal Peran Dinas Perindustrian, Perdagangan, Koperasi dan UKM ( Ilmu Permerintahan)

Totok gunawan dkk; 2007, Fakta dan Konsep Geografi, Inter Plus, Jakarta

Sudikmomeertokusumo, 1986, Mengenal Hukum, Liberty: Yogyakarta. 